\title{
PROMOTING LEARNING FROM HOME ENVIRONMENTS THROUGH GOOGLE CLASSROOM APPLICATION FOR EFL UNDERGRADUATES
}

\author{
Amrina Rosyada \\ Faculty of Languages and Art, Indraprasta PGRI University \\ 4mrin4@gmail.com
}

\begin{abstract}
Abstrak
Dunia yang tengah dikejutkan oleh wabah yang tidak diharapkan bernama COVID-19, terdorong untuk mengambil berbagai kebijakan darurat pada berbagai bidang kehidupan, termasuk pada bidang Pendidikan. Di Indonesia, di semua perguruan tinggi, utamanya yang berlokasi di wilayah zona merah, seperti kota Jakarta, sangat dibatasi aksesnya dalam beberapa bulan ke depan. Seтиa aktivitas di dalam area kampus sangat dibatasi sehingga pertemuan tatap muka ditiadakan dan diganti menjadi kelas virtual atau disebut dengan "pembelajaran dari lingkungan rumah". Oleh karena itu, penelitian ini memfasilitasi pembelajaran dari lingkungan rumah dengan memanfaatkan aplikasi Google Classroom sebagai media daring gratis dalam pengajaran English basic grammar bagi mahasiswa English as a Foreign Language (EFL). Penelitian ini diikuti oleh 60 mahasiswa Program Studi Pendidikan Bahasa Inggris, Universitas Indraprasta PGRI (Unindra) yang berlokasi di Jakarta, Indonesia. Pada penelitian ini dilaksanakan model penelitian dengan metode gabungan convergent yang mengumpulkan data melalui 2 siklus dan instrumen penelitian berupa tes dan kuesioner. Berdasarkan analisis korelasi dan analisis narasi, hasil penelitian menunjukkan luaran yang menarik pada aspek keikutsertaan dan pemahaman materi dari para pemelajar. Dengan dukungan fitur yang praktis dan sederhana, Google Classroom menjadi salah satu aplikasi pembelajaran yang menarik dan menjanjikan dalam pembelajaran bahasa Inggris dari lingkungan rumah selama masa pandemik.
\end{abstract}

Kata Kunci: Pembelajaran dari lingkungan rumah, aplikasi Google Classroom, pemelajar EFL, kelas virtual, masa pandemik

\begin{abstract}
As the world has been shocked by the unexpected rapid disease named COVID-19, several emergency actions are conducted in all aspects of human lives, including in the education field. In Indonesia, all colleges, particularly in several red-zone areas such as Jakarta, are restricted accessed for several months ahead. All activities inside the institutions' building are limited, and face-to-face classrooms are forbidden and changed into virtual classrooms or called Learning from Home Environments (LHE). Regarding the situation, this research is promoting LHE with the use of Google Classroom application as a free available media in teaching English basic grammar course for EFL undergraduates. This research was participated by 60 students of English Education Program, Universitas Indraprasta PGRI (Unindra), located in Jakarta, Indonesia. The research administered a convergent mixed-method research design by collecting data in two cycles that accumulated through tests and questionnaires. Based on research questions, a correlational analysis and a narrative analysis were allocated. The results indicate an interesting output on students' course engagement and course understanding. Supported by several practical and simple features, Google Classroom becomes a promising and favorite tool in learning English from home environments during the pandemic period.
\end{abstract}

Keywords: Learning from home environments, google classroom application, EFL undergraduates, virtual classroom, pandemic period 


\section{INTRODUCTION}

From the beginning of this year, the world has been shocked by the unexpected disease carried out by a novel corona virus named COVID-19. This virus has forced the world to conduct emergency actions in all aspects of human lives to prevent the outbreak, since a recent investigation stated that the disease is spread by human-to-human transmission via droplets or direct contact (Lai et al., 2020). In Indonesia, particularly in Jakarta where the rate of positive infected cases is the highest, all institutions of offices and schools are closed until several months ahead. The government published several instructions to slow down the spread of the disease and insisted the citizens to work from home, learn from home, and pray from home. In this way, all schools and colleges are forbidden to do the face-to-face classrooms. Teachers and lecturers are persuaded to administer virtual classrooms due to affordable technology devices, mostly through the smartphones. For some schools and colleges, the virtual classrooms are provided and supported by the institutions via online applications. However, for several schools and colleges, the teachers and the lecturers are freely arranging their suitable applications where the virtual classrooms are managed in several free online applications, such as Zoom, Discord, Line, Edmodo, and Google Classroom.

In the era of digital technology, the use of sophisticated media is increasingly required in relation to educational systems. Teachers and students are encouraged to use the technology as the tools in the learning process, due to the trend of the rapid changes of the educational environment. One of the most familiar tools in educational settings is the use of an online application that is abundantly available and freely accessed. Several online applications such as WhatsApp, Google Classroom, Google Translate, Google Drive, Edmodo, Zoom, Line, and many others are provided freely and easily installed. The online applications are very flexible to be installed in several devices, from smartphones to desktops. In this way, both teachers and students can learn anywhere, anytime, and for all subjects of education, including the learning of English language. In other words, the teachers-students engagement in the virtual classroom, particularly in English language learning is digitally effective (Latif, 2016).

In the rapid increased technology all over the world, the learning from home environments is not difficult since each country has its own learning management system. In fact, the use of online learning has actually been applied in education for years by utilizing several online materials through digital devices. The use of online materials has increased the learners' motivation and satisfaction in English learning, and significantly correlated to the learners' academic output (Solak \& Cakır, 2015). In Saudi Arabia, a study on home schooling was administered by applying Massive Open Online Courses (MOOCs) that designed to improve the quality of education as well as the collaboration among the learners of higher education (Brahimi \& Sarirete, 2015). A survey was conducted to evaluate the learners' perceptions on how the MOOCs had positive impact on home education. Based on the learners' responses, the results showed that $44.52 \%$ of the learners were strongly agree, $51.61 \%$ stated agree, and only $2.58 \%$ said agree nor disagree. The research proved that the use of MOOCs in education has brought positive changes on home learning.

In English as a Foreign Language (EFL) learning, another study was held in 2017 by applying an immersive English learning environment in a 3D virtual world. The study developed an Open Simulator with two key learning artefacts, chatbot and time machine. The study promoted four different learning conditions, namely: Virtual learning Environment without digital learning artefacts (VE), Virtual learning Environment with 
Chatbot (VEC), Virtual learning Environment with Time Machine (VETM), and Virtual learning Environment with Chatbot and Time Machine (VECTM), it revealed that the chatbot and time machine increased the learners' sense of immersion and presence (Wang et al., 2017). It also concluded that the best design practices should address how immersion and presence can be integrated into opportunities of virtual worlds. A year later, a research on EFL learning in high school level was employed. The research examined the influence of social factors on English learning trajectories and out-of-class English learning practices. In accordance to the learners' perspectives, the findings indicated the potential role of social interactions and social structure on both overall English learning trajectories and out-of-class English learning practices. The research provided practical suggestions to support students' English language development which covered promoting students' self-concept; creating quality home English language environment; and involving people in students' social network in school interventions (Chanjavanakul, 2018).

As a powerful tool, using high technology or often called as E-learning such as Google Classroom, is the most interesting option where almost everything is right on the screen. During the pandemic period, Google Classroom application becomes one of the most favorite and simply accessed application in learning from home environments. The Google Classroom performs a unique appearance and atmosphere that provides a central site for communicating with students, providing assignments and sending feedback. An evaluation was conducted to find out the effectiveness of the Google Classroom in submission process of the students' assignment; and it revealed that the use of Google Classroom is simplifying marks and assessment on the students' submitted assignment (Bhat et al., 2018). Another study unveiled that the Google Classroom augmented student participation and learning and boosted classroom dynamics due to the students' experience (Heggart \& Yoo, 2018). Both studies admitted the Google Classroom as an effective online application in the process of language learning.

In Indonesia, several studies on how Google Classroom has brought different educational circumstances were conducted. This application is part of the online Google Apps for Education (GAFE) that suits for teachers and students in an online learning. Moreover, the Google Classroom is said to be a simply manageable application in a learning process, particularly in terms of task management, for both students and lecturers. In other words, Google Classroom is effective in promoting students' learning independence and students' critical thinking (Ketut Sudarsana et al., 2019; Rahmad et al., 2019).

Regarding the uncertain situation of the pandemic period, the use of the online learning becomes the single option in education. The present study focuses on application of Google Classroom in learning English basic grammar for first year EFL undergraduates. As the educational setting has dramatically changed from the traditional face-to-face classrooms into the virtual classrooms, the use of technology contributes a crucial role on today's educational systems. Both lecturers and learners are insisted to learn from home environments and demanded to support an interactive and collaborative learning process. Ready or not, in this period, both lecturers and learners of EFL undergraduates have been persuaded to learn and develop on the digital literacies, in searching for the best practices for the virtual classrooms (Yuan et al., 2019). 


\section{RESEARCH METHOD}

The research was administering a mixed-method research design with convergent parallel design. In this design, Creswell (2012) explained that quantitative and qualitative data are collected at the same time and merged or converged in order to provide a comprehensive analysis of the research questions. The information from both data are integrated and presented as the overall results supported by several details and explanations of the findings. Compare to a qualitative research or a quantitative research as a single analysis, this mixed-method research design is rather time consuming, though covering a wide-ranging information and explanations. This research aims at answering three main questions on: 1) the effectiveness of the implementation of Google Classroom in learning English basic grammar on the first year EFL undergraduates understanding; 2) the most valuable aspects of Google Classroom application in learning English basic grammar based on students' perception; and 3) students' suggestions in improving the effectiveness of the implementation of Google Classroom in learning English basic grammar.

\section{Participants}

The participants were taken from two classes of 91 students at second semester of the academic year 2019/2020 in the English Education Program, Indraprasta PGRI University. To perform an empirical study, 60 students were selected randomly to answer the research questions (Patten et al., 2019). The participants comprised in 46 female students $(76.67 \%)$ and 14 male students $(23.33 \%)$. Despite the gender' distribution, all participants were treated equally in all procedures of the research.

\section{Research Instruments}

In this research, the data from the participants was collected through two set of research instruments. Two different instruments in a form of test and a set of questionnaires were assigned to assess two different variables of the research. The test consists of ten numbers on error analysis about several tenses in structured sentences, subject verb agreement, noun, and article. All numbers were taken and modified from the students' handbook by Azar and Hagen (2009). Each number was scored 10 that made 100 as the total score. Meanwhile, the questionnaire is a set of twenty statements in an ascending scaling score from 1 to 5 for each item and added on two open-ended questions related to the second and the third questions of the research. The questionnaire covered the students' perceptions on four elements of the Google Classrooms' implementation, namely: 1) practical features on Google Classroom; 2) skill and responsiveness of the lecturer; 3) course content; and 4) positive contributions of the Google Classroom to the students' learning. Each element contributed 25 points for the highest and put 100 points as the total score.

\section{Research Procedures}

This current research was organized in 5 stages based on Creswell and PlanoClark (2007), namely: 1) formulating research questions; 2) determining research design; 3) developing research instruments; 4) collecting and analysing data; and 5) interpreting and performing research findings. The participants were set to enrol English basic grammar course in face-to-face classroom for one semester from March to August 2020. However, related to Learning from Home Environments, the course was managed in 
shorter period where Google Classrooms application was implemented as the virtual classroom.

In this research, there were two cycles of Google Classroom implementation. There were four meetings in each cycle disseminating 3 meetings for course discussion and 1 meeting for assignment. For both cycles, the course materials were always delivered through Google Drive in a form of slides presentation. In the second cycle, the materials were enriched by several videos taken from Youtube. Based on the course materials, the participants were allowed to ask questions, complete several exercises, share their opinion or argumentations, and discuss the course materials due to related and valid sources. The participants managed the discussion in the comment column right below the course material or the lecturer's explanations. Meanwhile, the assignment was given through the Classwork section in the form of Google Form Quiz that had to be completed by the participants in scheduled time. Each meeting in Google Classroom was limited to exact time as in face-to-face classrooms.

\section{Data Collections and Analyses}

The data collections were accumulated on the 7th meeting for the first cycle; and on the 11th meeting for the second cycle. On those meetings, the participants were assigned a test and a set of questionnaires. All participants had to complete the questionnaire in 15 minutes then continued to finish the error analysis test for 60 minutes. In analyzing the errors, the participants had an opportunity to open their course materials or other sources to determine the correct answers before submitting the test.

Based on both instruments' answers, the collected data was analyzed statistically and descriptively performed in tables and charts with particular explanations. In collecting the data, both quantitative and qualitative data were acquired, scored, and summarized at the same time in the Classwork of Google Classrooms. Both of quantitative data and qualitative data were analyzed through correlational analysis and narrative analysis. The correlational analysis was carried out to determine prevalence and relationship between the two variables (Curtis et al., 2016). In this research, the first variable is the use of Google Classroom in learning English basic grammar course; and the second variable is the participants' understanding in English basic grammar course. In addition, a narrative analysis was also administered to identify and explore specific or unique results (Creswell, 2012). By combining both analyses, a comprehensive interpretation is possibly provided.

\section{RESULT AND DISCUSSION}

Based on the data collections through the research instruments, there are two scores for each participant that reflect the participant's respect on applying Google Classroom application in learning English basic grammar in one side; and in other side, express the participant's understanding on English basic grammar through the use of Google Classroom application. To perform a simple and logical description of the results, table 1 and table 2 display the differences of the collecting data in each cycle.

Table 1 Participants' Respect to GC

\begin{tabular}{lccccc}
\hline \multicolumn{1}{c}{ Cycles } & Highest & Lowest & Mean & Median & Mode \\
\hline First Cycle & 95 & 45 & 69.25 & 70 & 73 \\
Second Cycle & 95 & 41 & 75.55 & 77 & 79 \\
\hline
\end{tabular}


Table 2 Participants' Understanding the Basic Grammar through GC

\begin{tabular}{lcccccc}
\hline \multicolumn{1}{c}{ Cycles } & Highest & Lowest & Mean & Median & Mode & St. Dev. \\
\hline First Cycle & 100 & 25 & 71.58 & 75 & 100 & 23.37 \\
Second Cycle & 90 & 55 & 69.25 & 70 & 60 & 8.55 \\
\hline
\end{tabular}

\section{The effectiveness of applying Google Classroom application in English basic grammar course}

To determine the effectiveness of applying GC application in English basic grammar course, a correlational analysis was carried out in each cycle. The correlational analysis was measured due to Pearson Product Moment analysis with the significant value $\alpha=0.05$ and degree of freedom $=\mathrm{N}=60$. In first cycle, the $\mathrm{r}$ observed $=0.159$ compare to $r$ critical value $=0.254$, where the $r$ observed is lesser than $r$ table. This result means that there is no significant correlation between the variables. In this case, the participants perceived that applying Google Classroom application in English basic grammar course doesn't contribute significant effect on the participants' understanding of the English basic grammar course.

Moreover, the research continues to the next cycle. In second cycle, the r observed shows 0.034 compare to $r$ table $=0.254$ where the $r$ observed is still lesser than the $r$ table. The second cycle's result also indicates that there is no significant correlation between the independent variable and the dependent variable. In other words, the results in both cycles demonstrate insignificant relation or association between the applying Google Classroom in English basic grammar and participants' understanding of English basic grammar. It can be said that the applying Google Classroom contributes a little effectiveness in learning English basic grammar course in the level of undergraduates.

The results are in contrast to the aforementioned studies. Therefore, another analysis is needed to explore and obtain a comprehensive picture of the research. By employing a narrative analysis, several distinctive results are identified and possibly scrutinized. Based on the data, the distinctive results are displayed in the following figure 1 that informs the progressive of the participants understanding on English basic grammar through Google Classroom application in three categories: increasing, decreasing, and steady.

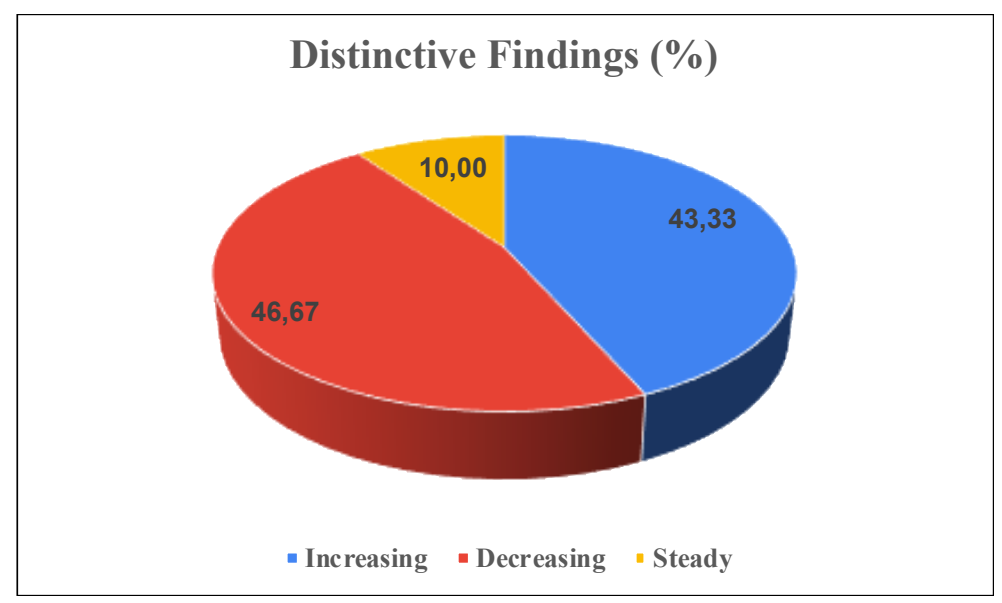

Figure 1 Distinctive Findings 
Figure 1 describes three categories of the participants progressiveness in understanding English basic grammar through the applying Google Classroom application. In increasing category, there are $43.33 \%$ of participants or 26 participants who have achieved their understanding English basic grammar increasingly. The increasing is varied from 5 to 50 points between the first cycle to the second cycle. The outstanding achievement was performed by 1 participant who increased the scores from 35 in first cycle to 85 in second cycle. The participant shows that Google Classroom application is simply operated and provide clear instructions features. The participant also appreciated the Google Classroom in alarming the participant's classwork to be completed as soon as possible before the classwork's dateline.

Continue to the second category, the decreasing achievement of the participants' scores in understanding English basic grammar through Google Classroom application. Figure 1 shows that there are $46.67 \%$ of the participants or 28 participants who are declining in their scores. The declining scores are varied from 5 points to 45 points. There were 2 participants who gained the extreme differences of 45 points. They claimed that Google Classroom doesn't bring more excitement in learning English basic grammar than they do in face-to-face classroom. In this way, they need practices more than additional features on Google Classroom to gain their deeper understanding in English basic grammar.

The last category expresses the steady category where there are $10 \%$ of the participants or 6 participants who do not gain inclining or declining scores from the first cycle to the second cycle. The participants' scores ranged from 65 to 80 in both cycles. They declared that features in Google Classroom do not sufficiently helped them in learning English basic grammar. They had to spend some time to learn how to operate Google Classroom so that they could catch up the lesson easily.

Based on the overall descriptions, despite the insignificant correlation between the applying Google Classroom and the participants' understanding in English basic grammar, several participants indicate inclining achievements on their understanding of the course. In this way, the applying Google Classroom application is partly effective to the participants' understanding English basic grammar in particular aspects, while partially ineffective. The results are very common for every new circumstance, especially in an unexpected nowadays situation. In the future, it is believed that applying Google Classroom application would greatly contribute to the EFL language learning, since this application can be operated in a multi direction process for both teachers and learners (AlMaroof \& Al-Emran, 2018).

Valuable aspects of Google Classroom application in English basic grammar course

In responding the second question of the research, the data was provided by the participants' answers on the questionnaire in an open-ended question. Most participants acknowledged that the most valuable aspect in Google Classroom application is its supporting in a classwork reminder so that the participants can submit their work on time. Moreover, the participants appreciated Google Classroom application for recording all the course material and the lecturer's explanations on the wall where the participants can re-read and re-watch any important notes of the course. As well as other online application, Google Classroom application allows the participants to learn anywhere and anytime, since all materials are right on their screen. 


\section{Improving the effectiveness of Google Classroom application in English basic grammar course}

To improve the effectiveness of Google Classroom application in learning English basic grammar course, several suggestions are recorded based on the participants' answers on the questionnaire. Some participants recommended to add features such as 'voice note' and 'move symbol'. The voice note is intended to help the participants understanding the materials explanations while the move symbol is enabling the participants to see several important notes from the lecturer directly. Other than those suggestions, all participants do greatly appreciate the Google Classroom as their media in learning English basic grammar course.

\section{CONCLUSION}

In respect to the advanced technology and communication, learning from home environments is a possible option in dealing with an unexpected situation during this pandemic period. By utilizing Google Classroom as one of the free online applications, learning from home environments in all levels of education becomes much easier for both teachers and learners. In learning English basic grammar course for EFL undergraduates, Google Classroom application has been appreciated in supporting the learning with simple and clear features, recording materials and discussion, and assignment reminder. Those valuable aspects would deliver greater impacts when supported by additional features such as voice notes and move feature where user or participants could easily understand the lesson and catch up any important notes on the discussion. However, as the internet connection is the major underpinning in this kind of virtual learning, several problems appeared to this matter (Alim et al., 2019). In this way, further educational circumstances have to be fully supported by unlimited coverage of internet connectivity and virtual learning system should be developed properly. Identically, while the infrastructure of the virtual learning system is physically constructed, technology literacy on educational system is supposed to be established (Richards, 2015). In this way, learning in the classroom settings or learning from home environments would not be limited.

\section{REFERENCES}

Azar, B., \& Hagen, S. (2009). Understanding and Using English Grammar. $4^{\text {th }}$ Ed. Pearson Education. NY.

Al-Maroof, R. A. S., \& Al-Emran, M. (2018). Students acceptance of google classroom: An exploratory study using PLS-SEM approach. International Journal of Emerging Technologies in Learning. https://doi.org/10.3991/ijet.v13i06.8275

Alim, N., Linda, W., Gunawan, F., \& Saad, M. S. M. (2019). The effectiveness of Google classroom as an instructional media: A case of state islamic institute of Kendari, Indonesia. Humanities and Social Sciences Reviews. https://doi.org/10.18510/hssr.2019.7227

Bhat, S., Raju, R., Bikramjit, A., \& D'souza, R. (2018). Leveraging e-learning through google classroom: A usability study. Journal of Engineering Education Transformations. https://doi.org/10.16920/jeet/2018/v31i3/120781 
Brahimi, T., \& Sarirete, A. (2015). Learning outside the classroom through MOOCs. Computers in Human Behavior. https://doi.org/10.1016/j.chb.2015.03.013

Chanjavanakul, N. (2018). "Learning without intending to": A qualitative study of high school students' out-of-class English learning practices. Dissertation Abstracts International Section A: Humanities and Social Sciences.

Creswell, J. W. (2012). Educational research: Planning, conducting, and evaluating quantitative and qualitative research. In Educational Research. https://doi.org/10.1017/CBO9781107415324.004

Creswell, J. W., \& Plano-Clark, V. (2007). CVhoosing a mixed methods design. Designing and conducting mixed method research (pp.62-79). California. Sage Publications.

Curtis, E., Comiskey, C., \& Dempsey, O. (2016). Importance and use of correlational research. Nurse Researcher. https://doi.org/10.7748/nr.2016.e1382

Heggart, K. R., \& Yoo, J. (2018). Getting the most from google classroom: A pedagogical framework for tertiary educators. Australian Journal of Teacher Education. https://doi.org/10.14221/ajte.2018v43n3.9

Lai, C. C., Shih, T. P., Ko, W. C., Tang, H. J., \& Hsueh, P. R. (2020). Severe acute respiratory syndrome coronavirus 2 (SARS-CoV-2) and coronavirus disease-2019 (COVID-19): The epidemic and the challenges. In International Journal of Antimicrobial Agents. https://doi.org/10.1016/j.ijantimicag.2020.105924

Latif, S. (2016). Learning Engagement in Virtual Environment. International Journal of Computer Applications. https://doi.org/10.5120/ijca2016911289

Patten, M. L., Galvan, M. C., Patten, M. L., \& Galvan, M. C. (2019). Random Sampling. In Proposing Empirical Research (4th ed., p. 200). Pyrczak Pub. https://doi.org/10.4324/9780429463013-35

Rahmad, R., Wirda, M. A., Berutu, N., Lumbantoruan, W., \& Sintong, M. (2019). Google classroom implementation in Indonesian higher education. Journal of Physics: Conference Series. https://doi.org/10.1088/1742-6596/1175/1/012153

Richards, J. C. (2015). The changing face of language learning: Learning beyond the classroom. RELC Journal. https://doi.org/10.1177/0033688214561621

Solak, E., \& Cakır, R. (2015). Exploring the effect of materials designed with augmented reality on language learners' vocabulary learning. Journal of Educators Online. https://doi.org/10.9743/jeo.2015.2.5

Sudarsana, I. K., Putra, I. B. M. A., Astawa, I. N. T., \& Yogantara, I. W. L. (2019). The use of Google classroom in the learning process. Journal of Physics: Conference Series. https://doi.org/10.1088/1742-6596/1175/1/012165 
Wang, Y. F., Petrina, S., \& Feng, F. (2017). VILLAGE-Virtual Immersive Language Learning and Gaming Environment: Immersion and presence. British Journal of Educational Technology. https://doi.org/10.1111/bjet.12388

Yuan, C., Wang, L., \& Eagle, J. (2019). Empowering english language learners through digital literacies: Research, complexities, and implications. Media and Communication. https://doi.org/10.17645/mac.v7i2.1912 